\title{
Application of DENTALQUAL Model in Measuring the Satisfaction of Domestic Dental Tourists During COVID-19 Pandemic
}

1 Dora Rašan

2 Lovro Rašan

1 Faculty of Tourism and Hospitality Management in Opatija, University of Rijeka

2 Department of Biotechnology, University of Rijeka tients on the ways of preventing other diseases (-0.52). Respondents asses the overall satisfaction with the given service with a high 4.47.

Conclusion: Research of quality and satisfaction of tourists with given dental service is of essential importance for the development of dental tourism in Croatia and therefore the analysis of SERVQUAL gap has proved to be an effective research model.

\begin{abstract}

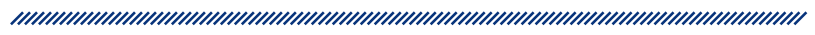

Introduction: With the expansive development of dental tourism in Croatia, there has sprung a need for research into the quality of dental services and satisfaction of tourists with the purpose of improvement and advancement of existing services.
\end{abstract}

Aim and Methods: The aim of this paper was to research and analyse the perception of dental tourists on the quality of dental services and to analyse their overall satisfaction. The measuring instrument used in this study was a modified DENTALQUAL model.

Results: Looking at the results of the empiric research, it has been determined that respondents have high expectations about quality of dental services (4.65). When it comes to the perceived quality of services, total average grade of the respondent's perception of the given dental service was 4.50 , which shows the presence of the negative SERVQUAL gap (-0.15). Respondents find cleanliness and tidiness of the interior and instruments the most important (4.97), and they are mostly unsatisfied with the dentist's attitude towards consulting pa-
Keywords: SERVQUAL model, dental tourism, service quality, COVID-19, statistic analysis

Article received: 1.12.2021.

Article accepted: 30.12 .2021 .

https://doi.org/10.24141/1/8/1/6

\section{Corresponding author:}

Dora Rašan

A: University of Rijeka, Faculty of Tourism and Hospitality

Management, Opatija, Croatia

E-mail: dora.rasan1996@gmail.com

T: +385997538633 


\section{Introduction}

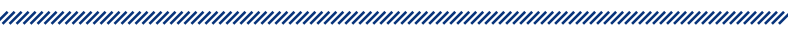

In the course of history, one of the basic motives for travelling was to preserve and improve the health of people and in accordance with this, health tourism started developing gradually. Health tourism is a complex tourist product which includes a large number of specialised contents and services during travels motivated by the need to improve health and enhance the quality of life. ${ }^{1}$ In the Republic of Croatia, one of the most propulsive forms of health tourism which attracts a large number of patients from abroad is dental tourism. Loubeau ${ }^{2}$ defines dental tourism as the intention of a country or a destination to attract tourists by promoting their dental services as a complement to basic tourist content.

According to Dental Tourism Croatia ${ }^{3}$, the most common reason why dental tourists come to a country is the cheap price of high-quality dental services, and the price is solely feasible due to low labor cost, education and training of the staff and low cost of opening a dental practice. The cost of dental treatment in Croatia is 50 to $70 \%$ lower compared to Western European countries, so it is more profitable for patients from neighbouring countries to take a short trip to Croatia which enables a significantly lower cost of dental services. $^{4}$

It is also important that other elements influence the choice of destination of dental tourists, such as the distance and attractiveness of a destination, recreational possibilities and the like. ${ }^{5}$ Since Croatia has a high potential to become a leader in the domain of dental tourism, the aim of this empirical research was to explore and analyse the attitudes of dental clients on the quality of provided service and to analyse their overall satisfaction. However, due to the present COVID-19 pandemic, it was not possible to include foreign tourists in the sample, but only domestic dental tourists.

\section{Literature overview}

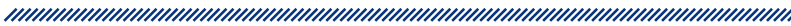

\section{Concept of service quality}

The concept of quality comes from Latin, from the word "qualitas" which when translated represents property, merit, feature, ability and value. ${ }^{6}$ However, in different historical periods, the meaning of the concept of quality was subject to change. The term quality was first mentioned in the Bible and has assumed a positive meaning, while in the Phoenicians time quality was in the economic sense perceived as something good or bad and every deviation from good, or from the required quality of products and services was punished by cutting ones hand. ${ }^{7}$ Therefore, quality has always been present in everyday life and business of people in all historical periods, so it is of significant importance to understand how to manage it in a proper way.

However, comprehension, understanding and managment of quality are of critical importance to determine the differences between products and services. Therefore, the majority of research done by the end of 1970 s was focused primarily on the research of quality in the field of goods, and since the 1980s, research started to be conducted in the field of quality of services. The cause of incomparable development of the concept is complexity in defining and measuring the service quality. More precise, because of the intangibility, indivisibility, variability, transience and diversity of services. ${ }^{8}$

According to all, the quality of service is very difficult to define and still there is no universal definition of the term. Among various authors who have tried to describe the problem, Gronroos ${ }^{9}$ suggested his formulation and he characterised the concept as ", result of consumers' comparison between their expectations and perception". In a similar way, Mackay and Crompton ${ }^{10}$ have interpreted the quality of service by stating that the service quality is "a relationship between what consumer wants and his perception of the provided". In previous definitions, it is visible that the stress is put on the difference between the expectation before purchase and the clients' perception after purchase or delivery of a service. 


\section{Measuring the dental service quality and client satisfaction}

For the last couple of decades, more emphasis has been put on the higher need for measuring service quality with the aim of achieving competitive advantage in the market. Regarding the complexity of services in scientific research, there are different approaches to measurements which are seen in the development and usage of various models. The literature mostly mentions the SERVQUAL model for measuring the service quality and satisfaction of clients. The model was created by Parasuraman, Berry and Zeithaml. ${ }^{11}$ Firstly, the model had ten dimensions which were, after the conducted research, reduced to five, and these are: (1) tangibility, (2) reliability, (3) responsibility, (4) assurance and (5) empathy. ${ }^{12}$

The main purpose of using this instrument is to find the gap between the client's expectation and his/her perception of the provided service. ${ }^{13}$ It is natural that there are discrepancies between expectation and perception, but by early diagnosing the discrepancies, there is a higher possibility that they are, with good management, reduced or completely removed by managers with the aim of achieving the long-term level of high service quality and client satisfaction.

The mentioned model was used to measure the service quality in a number of service industries, and also in health tourism. ${ }^{14}$ By looking at the scientific literature from around the world, it is possible to conclude that the SERVQUAL model is also a suitable and valid instrument for measuring the quality of dental services and has as such been used in a number of studies around the world: North America ${ }^{15,16}$, South America ${ }^{17}$, Asia ${ }^{18-23}$, Australia $^{24}$ and Europe ${ }^{25,26}$.

\section{Methodology}

This empirical research used a method of questionnaire to obtain primary data and an online and onsite questionnaire was used as a measuring instrument. The basis for constructing the questionnaire was a modified the SERVQUAL model. ${ }^{12}$ Since the study is specifically in the field of dental tourism, the research done by Akbar and associates ${ }^{18}$ was used as the basis. Questioning of domestic tourists was conducted between September and October 2020 and 176 correctly filled out questionnaires were gathered. The following parts make up the structure of the measuring instrument:

- Expected dental service quality (items 1 to 25);

- Perceived dental service quality (items 26 to 50);

- Overall dental tourists' satisfaction (item 51) and

- Sociodemographic profile (items 52 to 58).

The first two parts of the questionnaire had 50 statements which assessed expectations (25 statements) and perception (25 statements) of dental tourists on the provided service quality. The third part of the questionnaire inquired the overall satisfaction of domestic tourists with the provided dental service quality with the following statement: „How do you grade the provided service in a dental practice?". Statements from the first three parts were graded by using the Likert scale with five response options, where 1 means „I completely disagree“, and 5 means „I completely agree“. The last part of the questionnaire contains statements used to analyse the respondents' sociodemographic profile: age, gender, marital status, education, monthly income and frequency of dental visits.

\section{The results of empirical research}

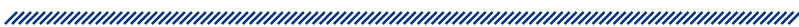

Based on the conducted research of the tourist's satisfaction with the quality of dental services, the obtained results are shown in tables. Table 1 shows the sociodemographic profile of respondents in order to gain insight into their structure and the following tables show the results of descriptive statistic analyses.

When it comes to marital status, 40 out of 176 respondents $(22.73 \%)$ are married, 39 are in a relationship or are engaged and they make $22.16 \%$ of all the respondents, and 97 respondents (55.11\%) are not married or in a relationship. Looking at education structure, more than half of the respondents have a high school diploma $(52.27 \%)$, then the ones with a university degree $(40.34 \%)$ and then respondents with a Ph.D. (5.68\%). The smallest number of respondents have only completed primary education (1.70\%).

Considering employment status, the largest number 


\section{Table 1. Sociodemographic profile}

\begin{tabular}{|c|c|c|}
\hline \multirow{2}{*}{ RESPONDENT CHARACTERISTICS } & \multicolumn{2}{|c|}{ FREQUENCIES } \\
\hline & ABSOLUTE & RELATIVE (\%) \\
\hline \multicolumn{3}{|c|}{ Gender } \\
\hline Male & 63 & $35.80 \%$ \\
\hline Female & 113 & $64.20 \%$ \\
\hline \multicolumn{3}{|c|}{ Age } \\
\hline under 16 & 0 & $0.00 \%$ \\
\hline $16-25$ & 105 & $59.66 \%$ \\
\hline $26-35$ & 16 & $9.09 \%$ \\
\hline $36-45$ & 27 & $15.34 \%$ \\
\hline $46-55$ & 22 & $12.50 \%$ \\
\hline $56-65$ & 6 & $3.41 \%$ \\
\hline Older than 66 & 0 & $0.00 \%$ \\
\hline \multicolumn{3}{|c|}{ Marital status } \\
\hline Married & 40 & $22.73 \%$ \\
\hline In a relationship/engaged & 39 & $22.16 \%$ \\
\hline Single & 97 & $55.11 \%$ \\
\hline \multicolumn{3}{|c|}{ Education } \\
\hline Elementary school & 3 & $1.70 \%$ \\
\hline High school diploma & 92 & $52.27 \%$ \\
\hline University degree & 71 & $40.34 \%$ \\
\hline Ph.D. & 10 & $5.68 \%$ \\
\hline \multicolumn{3}{|c|}{ Employment status } \\
\hline Part-time employment & 7 & $3.98 \%$ \\
\hline Full-time employment & 64 & $36.36 \%$ \\
\hline Self-employed & 8 & $5.68 \%$ \\
\hline Unemployed & 10 & $4.55 \%$ \\
\hline Retired & 3 & $1.70 \%$ \\
\hline Student & 84 & $47.73 \%$ \\
\hline \multicolumn{3}{|c|}{ Monthly income/kn } \\
\hline Up to 3500 & 30 & $17.05 \%$ \\
\hline $3501-5000$ & 21 & $11.93 \%$ \\
\hline $5001-10000$ & 41 & $23.30 \%$ \\
\hline $10001-15000$ & 9 & $5.11 \%$ \\
\hline More than 15000 & 2 & $1.14 \%$ \\
\hline No income & 73 & $41.48 \%$ \\
\hline \multicolumn{3}{|c|}{ Frequency of dental visits } \\
\hline Several times a month & 1 & $0.57 \%$ \\
\hline Once a month & 14 & $7.95 \%$ \\
\hline Once in three months & 35 & $19.89 \%$ \\
\hline Once in six months & 67 & $38.07 \%$ \\
\hline Once a year & 59 & $33.52 \%$ \\
\hline
\end{tabular}




\section{Table 2. Results of descriptive statistic analysis $(\mathbf{N}=\mathbf{1 7 6})$}

\begin{tabular}{|c|c|c|c|c|c|}
\hline \multirow[b]{2}{*}{ Statements } & \multicolumn{2}{|c|}{ EXPECTATIONS } & \multicolumn{2}{|c|}{ PERCEPTION } & \multirow[b]{2}{*}{ SERVQUAL GAP } \\
\hline & $\mathrm{AM}$ & SD & $\mathrm{AM}$ & SD & \\
\hline Modern equipment. & 4.69 & 0.563 & 4.36 & 0.836 & -0.34 \\
\hline $\begin{array}{c}\text { Cleanliness, tidiness and adequate clothing } \\
\text { of staff. }\end{array}$ & 4.94 & 0.341 & 4.79 & 0.485 & -0.15 \\
\hline $\begin{array}{l}\text { Cleanliness and tidiness of interior (waiting } \\
\text { room, tables, chairs, toilets and floors). }\end{array}$ & 4.97 & 0.211 & 4.67 & 0.636 & -0.30 \\
\hline $\begin{array}{l}\text { Visual attractiveness of brochures and } \\
\text { dental practice. }\end{array}$ & 4.21 & 0.873 & 4.13 & 1.045 & -0.09 \\
\hline $\begin{array}{c}\text { Cleanliness, tidiness and high quality of } \\
\text { equipment and materials for treating } \\
\text { patients. }\end{array}$ & 4.97 & 0.211 & 4.77 & 0.563 & -0.20 \\
\hline $\begin{array}{l}\text { Simplicity and practicality of payment } \\
\text { methods for additional dental services. }\end{array}$ & 4.84 & 0.479 & 4.56 & 0.776 & -0.28 \\
\hline Easily accessible parking space. & 4.43 & 0.839 & 4.56 & 0.853 & 0.13 \\
\hline $\begin{array}{l}\text { Providing services at a set time (date and } \\
\text { hour). }\end{array}$ & 4.77 & 0.580 & 4.31 & 1.063 & -0.46 \\
\hline Fulfilment of promises in a timely manner. & 4.56 & 0.699 & 4.44 & 0.892 & -0.12 \\
\hline $\begin{array}{c}\text { Clarity and intelligibility when explaining } \\
\text { the course of treatment. }\end{array}$ & 4.89 & 0.329 & 4.52 & 0.997 & -0.38 \\
\hline $\begin{array}{l}\text { Quality and long-term efficiency of dental } \\
\text { treatment. }\end{array}$ & 4.92 & 0.345 & 4.46 & 0.967 & -0.46 \\
\hline $\begin{array}{c}\text { Counselling patients on ways of preventing } \\
\text { other diseases. }\end{array}$ & 4.70 & 0.697 & 4.18 & 1.165 & -0.52 \\
\hline Staff provide fast and affordable services. & 4.53 & 0.755 & 4.70 & 0.919 & 0.16 \\
\hline $\begin{array}{l}\text { Informing patients on the set time of } \\
\text { providing a service. }\end{array}$ & 4.24 & 0.875 & 4.53 & 1.013 & 0.30 \\
\hline $\begin{array}{l}\text { Staff find the time to answer the patient's } \\
\text { questions. }\end{array}$ & 4.33 & 0.916 & 4.57 & 0.797 & 0.24 \\
\hline Staff is willing to help the patients. & 4.73 & 0.590 & 4.63 & 0.789 & -0.10 \\
\hline Courtesy of staff. & 4.78 & 0.544 & 4.69 & 0.748 & -0.10 \\
\hline Ensuring the patient's privacy. & 4.72 & 0.641 & 4.54 & 0.848 & -0.18 \\
\hline $\begin{array}{l}\text { Dentist is familiar with modern technology } \\
\text { and newest methods of treatment. }\end{array}$ & 4.73 & 0.580 & 4.48 & 0.821 & -0.24 \\
\hline Professionalism in providing services. & 4.92 & 0.406 & 4.63 & 0.775 & -0.29 \\
\hline Good reputation. & 4.44 & 0.730 & 4.45 & 0.820 & 0.01 \\
\hline $\begin{array}{l}\text { Staff pay individual attention to patients } \\
\text { during counselling (fast, simple and } \\
\text { effective). }\end{array}$ & 4.76 & 0.534 & 4.55 & 0.826 & -0.21 \\
\hline Staff listen to patient's opinions. & 4.32 & 0.883 & 4.36 & 1.043 & 0.03 \\
\hline $\begin{array}{c}\text { Understanding of the patient's specific } \\
\text { needs. }\end{array}$ & 4.63 & 0.638 & 4.46 & 0.919 & -0.16 \\
\hline $\begin{array}{l}\text { In the patient's best interest, staff ensure } \\
\text { accessible prices of dental services. }\end{array}$ & 4.56 & 0.761 & 4.30 & 1.028 & -0.26 \\
\hline
\end{tabular}

Note: AM - arithmetic mean; SD - standard deviation 


\begin{tabular}{|c|c|c|c|c|c|}
\hline \multirow{2}{*}{ Table 3. Results of descriptive statistics according to dimensions (N=176) } \\
\cline { 2 - 5 } DIMENSIONS & \multicolumn{2}{|c|}{ EXPECTATIONS } & PERCEPTION & \multirow{2}{*}{ SERVQUAL GAP } \\
\cline { 2 - 5 } & AM & SD & AM & SD & \multirow{2}{*}{-0.17} \\
\hline Tangibility & 4.72 & 0.446 & 4.55 & 0.193 & -0.39 \\
\hline Reliability & 4.77 & 0.183 & 4.38 & 0.103 & 0.15 \\
\hline Responsibility & 4.46 & 0.146 & 4.61 & 0.107 & -0.16 \\
\hline Assurance & 4.72 & 0.120 & 4.56 & 0.040 & -0.15 \\
\hline Empathy & 4.57 & 0.151 & 4.42 & 0.102 & -0.15 \\
\hline TOTAL & 4.65 & - & 4.50 & - & - \\
\hline
\end{tabular}

Note: AM - arithmetic mean; SD - standard deviation

of respondents $(47.73 \%)$ are pupils or students, then $36.36 \%$ of respondents are employed full-time, 3.98\% are employed part-time, $5.68 \%$ are self-employed, $4.55 \%$ of respondents are unemployed and $1.70 \%$ are retired people.

The largest number of respondents $(41.48 \%)$ stated that they have no income, while $23.30 \%$ of respondents have an income from 5001 to 10000 kunas. According to the frequency of dental visits, most respondents use dental services once in six months (38.07\%), 33.52\% use dental services once a year, and only one respondent uses dental services several times every month.

Respondents' expectations and perception of the quality of dental services are shown using the average mean in Table 2 and it can be seen that average means for all items regarding the respondents' expectation and perception are higher than 4.

On the expectation scale, statement connected to the visual attractiveness of brochures and dental practice has been given the lowest average grade (4.21), while the statements connected with cleanliness and tidiness of interior (waiting room, tables, chairs, toilets and floors) and cleanliness, tidiness and high quality of equipment for treating patients were given the highest average grades (4.97). Based on the best-graded statements from the expectation scale, we can state that for dental tourists, cleanliness and tidiness is of crucial importance.

On the other side of the perception scale, respondents think that dentists do not stress enough the importance of counselling patients on prevention and the lowest graded item is counselling patients on the ways of preventing other diseases (4.18). Dental tourists are most content with cleanliness, tidiness and adequate clothing of staff and this item has been graded with 4.79.
Furthermore, in 19 out of 28 items, there is a negative SERVQUAL gap, and in only 9 items there is a positive gap between tourists' perception and expectation. The biggest negative gap $(-0.52)$ is present in the item on consulting patients about the ways of preventing other diseases, and the biggest positive gap (0.30) is found in the item on informing patients on the precise time of providing a service.

Table 3 shows the average means of tourists' expectation and perception of the quality of services with SERVQUAL gaps for each dimension. With every dimension of the service quality, there is a discrepancy between perception and expectation ranging from -0.39 to +0.15 .

Regarding the tourists' expectations, dimensions of tangibility, reliability, empathy and assurance have average grades higher than 4.50 , while responsibility is the only dimension with lower average grade from the above mentioned (4.46). The highest negative discrepancy is noticed with the dimension of reliability $(-0.39)$ and within the mentioned dimension the lowest graded statement is providing a service at a set time (date and hour). Furthermore, although according to expectations, the lowest graded dimension is responsibility, it is the only dimension where a positive SERVQUAL gap of 0.15 is present.

The overall average grade of expectations within dimensions is 4.64 and of perception 4.50 , which shows that expectations are higher than the perception of tourists $(-0.15)$. So, it can be said that the provided service quality is unsatisfactory in some parts. However, regarding the fact that the discrepancies in both negative and positive numbers are minor, the conclusion that imposes itself is that there are no bigger discrepancies between the perceived quality of services and the tourists' expectations. 
Table 4. Results of descriptive statistic analysis of respondents satisfaction $(\mathbf{N}=\mathbf{1 7 6})$

\begin{tabular}{|c|c|c|c|}
\hline Statement & Min & Max & AM \\
\hline $\begin{array}{c}\text { How do you grade provided service in a dental } \\
\text { practice? }\end{array}$ & 1 & 5 & 4.47 \\
\hline
\end{tabular}

Note: Min - minimum; Max - maximum; AM - average mean; SD - standard deviation

By looking at the results from Table 4, we can conclude that dental tourists are generally satisfied with the provided dental service, which can be supported by a high average grade in the amount of 4.47 .

\section{Conclusion}

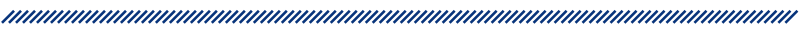

Tourism is becoming one of the leading economic branches in Croatia and the world. Therefore, it is necessary to constantly upgrade and provide new content for the tourists. Due to bigger transitions of people and low prices of dental services, Croatia is slowly establishing itself as a desirable location for dental tourism. The quality of dental services is of significant importance for the development of dental tourism and it is crucial to determine the level of patients' satisfaction with the provided dental service.

High average means for all the items show great expectations of respondents when it comes to the quality of dental services. However, only 6 of 25 tested items has a positive SERVQUAL gap between perception and expectation, while in 19 items respondents believe that the service is below the expected quality so it is important to improve it by appropriate techniques and methods. Although most respondents claim that the quality of dental services is below the expected level, this discrepancy between perception and expectation does not exceed -0.52 in all the items, which shows slight respondents' discontent.

Furthermore, respondents consider the attractiveness of brochures and dental practice the least relevant item, while the cleanliness of the practice and staff are considered to be the most valid. Respondents are dissatisfied with the attitude of dentists towards consulting and prevention of other diseases and the factor of consulting patients on the ways of preventing other diseases has the highest negative gap (4.18).
Informing patients about the time of providing the service is not high on the scale of expectations. However, respondents are very satisfied with how dentists notify their patients about the time of providing a service so the mentioned item has the highest positive discrepancy.

According to the respondents' opinion, the dentists' reliability is at a high level and this dimension has a higher perception than expectation. Other dimensions have a negative discrepany between perception and expectation and respondents think that tangibility, reliability, assurance and empathy is something that dentists should improve and work on. The overall average grade of respondents' satisfaction with the dental service quality is a high 4.47 . Therefore, we can conclude that the quality of dental services is generally satisfactory. The biggest improvements are needed in the presentation and prevention of potential diseases and dentists should spend more time raising patients' awareness on possible diseases.

Demand for dental services is increasing and therefore, the quality of services should also follow the ascending trend. This is why research based on expectations and perception of the service quality is of significant importance and the number of research focused on the quality of dental services should also increase. This research was conducted in the times when the freedom of movement between countries was decreased, it was not possible to obtain perceptions and attitudes of foreigners on the quality of dental services in Croatia. Future research should focus more on the perception and attitudes of foreign tourists, onsite research and the development of dental tourism as one of the important branches of the Croatian economy. 


\section{References}

1. Marković S, Škifić L, Rasz A. Primjena modela SERVQUAL u mjerenju kvalitete usluga u Thalasso wellness centru Opatija. Journal of Applied Health Sciences; 2020, 6(2) : 189-200.

2. Loubeau PR. The globalization of dental care: An opportunity for Croatian tourism. Tourism: An International Interdisciplinary Journal; 2009, 57(2) : 193-199.

3. Dental tourism Croatia. [Internet]; (2013). Available on: https://issuu.com/uzap/docs/dental_tourism_croatia_ big (pristupljeno 5.11.2020.)

4. Gregorić M, Sečan M, Pomper R, Miklik M. Prilike za razvoj poduzetništva u okviru dentalnog turizma u Hrvatskoj. Obrazovanje za poduzetništvo-E4E: znanstveno stručni časopis o obrazovanju za poduzetništvo; 2019, 19(2) : 85100.

5. Jurišić E, Radović T. Dental tourism-an opportunity for Croatian tourism. Interdisciplinary Management Research XIII. 2017, $18:$ 297-311.

6. Klaić, B. Rječnik stranih riječi, 1979, Zagreb: Nakladni zavod Matice Hrvatske.

7. Avelini - Holjevac I. Upravljanje kvalitetom u turizmu i hotelskoj industriji, 2002, Opatija : Fakultet za turistički i hotelski menadžment.

8. Kotler P, Keller K, \& Martinović M. Upravljanje marketingom, 2014, Zagreb: Mate i Zagrebačka škola ekonomije i menadžmenta.

9. Gronroos, C. A Service Quality Model and its Marketing Implications. European Journal of Marketing; (1984), $18(4)$ : 36-44. Available on: https://doi.org/10.1108/ EUM0000000004784

10. MacKay KJ, Crompton JL. Measuring the quality of recreation services. Journal of Park and Recreation Administration; 1990, 8(3) : 47-56.

11. Parasuraman A, Zeithaml VA, Berry LL. A conceptual model of service quality and its implications for future research. Journal of marketing; 1985, 49(4) : 41-50. Available on: https://doi.org/10.2307/1251430

12. Parasuraman A, Zeithaml VA, Berry LL. SERVQUAL: A multi-item scale for measuring customer perception of service quality. Journal of Retailing; 1988, 64(1) : 12-40.

13. Lohr KN, Schroeder SA. A strategy for quality assurance in Medicare. New England Journal of Medicine; 1990, 8(10) : 707-712. Available on: https://doi.org/10.1056/ nejm199003083221031

14. Marković S, Lončarić $D$, Lončarić $D$. Service quality and customer satisfaction in the health care industry Towards health tourism market. Tourism and hospitality management; 2014, 20(2) : 155-170.

15. Kaldenberg D, Becker BW, Browne BA, Browne WG. Identifying service quality strengths and weaknesses using SERVQUAL: a study of dental services. Health marketing quarterly; 1998,15(2) : 69-86. Available on: https://doi. org/10.1300/J026v15n02_04

16. Kress Jr GC. Patient satisfaction with dental care. Dental Clinics of North America; 1988, 32(4) : 791-802.

17. Rocha J, Pinto A, Batista M, de Paula JS, Ambrosano G. The importance of the evaluation of expectations and perceptions to improve the dental service quality. International journal of health care quality assurance; 2017 , 30(6) : 568-576. Available on: https://doi.org/10.1108/ IJHCQA-01-2016-0008

18. Akbar FH, Pasinringi $\mathrm{S}$, Awang $\mathrm{AH}$. Factors affecting dental center service quality in indonesia. Pesquisa Brasileira em Odontopediatria e Clínica Integrada; 2019, 19(1) : 1-11. Available on: https://doi.org/10.4034/PBOCl.2019.191.53

19. Bahadori M, Raadabadi M, Ravangard R, Baldacchino D. Factors affecting dental service quality. International journal of health care quality assurance; 2015, 28(7) : 678-689. Available on: https://doi.org/10.1108/ IJHCQA-12-2014-0112

20. Dewi FD, Sudjana G, Oesman YM. Patient satisfaction analysis on service quality of dental health care based on empathy and responsiveness. Dental research journal; 2011, 8(4) : 172-189. Available on: https://doi. org/10.4103/1735-3327.86032

21. Dopeykar N, Bahadori M, Mehdizadeh P, Ravangard R, Salesi M, Hosseini SM. Assessing the quality of dental services using SERVQUAL model. Dental research journal; 2018, 15(6) : 430-444. Available on: https://doi. org/10.4103/1735-3327.245230

22. John J, Yatim FM, Mani SA. Measuring service quality of public dental health care facilities in Kelantan, Malaysia. Asia Pacific Journal of Public Health; 2011, 23(5) : 742-53. Available on: https://doi.org/10.1177/101053950935734

23. Adebayo ET, Adesina BA, Ahaji LE, Hussein NA. Patient assessment of the quality of dental care services in a Nigerian hospital. Journal of Hospital Administration; 2014, 3(6) : 20-28. Available on: https://doi.org/10.5430/ jha.v3n6p20

24. Baldwin A, Sohal A. Service quality factors and outcomes in dental care. Managing Service Quality: An International Journal; 2003, 13(3) : 207-216. Available on: https:// doi.org/10.1108/09604520310476472

25. Karydis A, Komboli-Kodovazeniti M, Hatzigeorgiou D, \& Panis V. Expectations and perceptions of Greek patients regarding the quality of dental health care. International Journal for Quality in Health Care; 2011, 3(2) : 50-58. Available on: https://doi.org/10.1093/intqhc/13.5.409

26. Palihawadana D, Barnes BR. The measurement and management of service quality in dental healthcare. Health services management research;2004,17(4):229-236. Available on: https://doi.org/10.1258/0951484042317750 


\section{PRIMJENA MODELA DENTALQUAL U MJERENJU ZADOVOLJSTVA DOMAĆIH DENTALNIH TURISTA U VRIJEME PANDEMIJE BOLESTI COVID-19}

1 Dora Rašan

2 Lovro Rašan

1 Fakultet za menadžment u turizmu i ugostiteljstvu u Opatiji, Sveučilište u Rijeci

2 Odjel za biotehnologiju, Sveučilište u Rijeci voljstvo pruženom uslugom ispitanici vrednuju s visokih 4,47.

Zaključak: Istraživanje kvalitete i zadovoljstva turista pruženom dentalnom uslugom bitno je za razvoj dentalnog turizma u Hrvatskoj te se izračun SERVQUAL jaza pokazao kao efektivan model istraživanja.

\section{Sažetak}

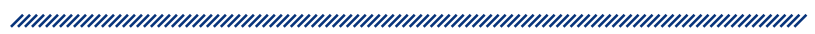

Uvod: Ekspanzivnim razvojem dentalnog turizma u $\mathrm{Hr}$ vatskoj javila se potreba za ispitivanjem kvalitete dentalnih usluga i zadovoljstva turista u cilju poboljšanja i unaprjeđenja postojećih usluga.

Cilj i metode: Cilj ovog rada bio je istražiti i analizirati percepciju dentalnih turista o kvaliteti dentalnih usluga i analizirati njihovo sveukupno zadovoljstvo. Mjerni instrument primijenjen u ovom istraživanju bio je modificirani model DENTALQUAL.

Rezultati: Rezultatima provedenoga empirijskog istraživanja utvrđeno je da ispitanici posjeduju visoka očekivanja o kvaliteti dentalnih usluga $(4,65)$. $\mathrm{S}$ obzirom na percipiranu kvalitetu usluga, ukupna prosječna ocjena percepcije pružene dentalne usluge iznosi 4,50, što ukazuje na prisutnost negativnog SERVQUAL jaza $(-0,15)$. Ispitanicima je najvažnija čistoća i urednost interijera i instrumenata $(4,97)$, a najnezadovoljniji su odnosom doktora dentalne medicine prema savjetovanju pacijenata o načinima sprječavanja drugih bolesti $(-0,52)$. Ukupno zado-

Ključne riječi: model SERVQUAL, dentalni turizam, kvaliteta usluga, COVID - 19, statistička analiza 